\title{
Finnsheep and their crosses under subtropical conditions
}

\author{
A. M. ABOUL-NAGA
}

Animal Production Research Institute, Ministry of Agriculture, Dokki, Cairo

\begin{abstract}
Finnsheep (F) have been introduced to eight countries in the subtropical Near East region over the last two decades. Those trials aiming at breeding pure $\mathrm{F}$ under the subtropical conditions were generally not successful. Pure F faced problems of adaptability to the subtropical environmental conditions, however, bad management and some health problems (especially Pneumonia) contributed significantly to the failure of some trials.

On the other hand, crossbreeding trials with $\mathrm{F}$ in the region were generally successful. F-crosses proved to be well adapted to heat stress and exposure to solar radiation compared with the local breeds. Number of lambs born/ewe lambed was improved in F-crosses, as compared to local breeds, by $18-75 \%$ in the first cross and $10-38 \%$ in the $1 / 4 \mathrm{~F}$. F-crossbred ewes showed encouraging results in their ability to breed more than once/year, especially those with lower F-blood (1/4F). Number of lambs born/ewe/year in accelerated lambing systems ranged from 1.91 to 2.72 in the first cross and from 1.67 to 2.18 in $1 / 4 \mathrm{~F}$ either in experimental farms or at the producers. Crossing fat tail sheep with F substantially decreased fat in the tail of the crossbreeds, while it increased significantly internal fat and total fat percentage in the carcass.
\end{abstract}

Index words: Finnsheep, subtropics, crossbreeding, adaptation, fertility, prolificacy, sexual maturity, growth, carcass

\section{Introduction}

Lamb production is an important activity in the subtropical Near East (NE) region as a main source of meat and a major source of income for good part of the population. Trials for improving lamb production from local sheep involving the introduction of temperate breeds have been widely made for a long time in the region, including recently Finnsheep (F).

Over the last two decades, eight NE coun- tries have imported $\mathrm{F}$ sheep, mainly to cross it with local sheep to improve prolificacy, but purebred $\mathrm{F}$ was sometimes raised under the subtropical conditions. According to the Finnish Sheep Breeders Association the first importation of $\mathrm{F}$ sheep from Finland to the region was in 1969 by a private breeder to $\mathrm{Al}$ geria ( 25 ewes +2 rams). It was followed in 1970 by successive batches of rams, and some ewes, to Egypt and Israel (3). Single importation of small flocks to each of Cyprus, Lebanon and Iran was carried out early in the 
seventies. The largest importations were those to Libya and Iraq where each country imported hundreds of $\mathrm{F}$ ewes plus some rams.

Furthermore, some F sheep were introduced to the region from second country as the ram batches imported to Egypt from UK and USA and the flock imported to Iraq from Yugoslavia.

\section{Breeding plans and objectives}

Table (1) summarizes breeding plans and objectives of eight trials executed in six NE countries. Those of Algeria and Iran could not be traced as they were carried out by private breeders. The most significant trials according to the number of animals involved, duration and available information are those of EMOA (Egypt) and IARO (Israel). Those of NASC (Egypt), CMOA (Cyprus), AUB (Lebanon) and IFAO (Iraq) were smaller in scale and few reports are available on them. The Libyan trial followed by IMOA (Iraq) were the biggest as far as number of imported animals is concerned. However, they were terminated after few years with no reports. Information was available only through personal communication.

Two objectives could be postulated among different trials, the main one is crossing the imported F rams to the local ewes to improve their prolificacy. After the 1st cross, crossbreeding is continued toward higher or lower grades, or in some cases utilized the 1st cross as dam line for fat lamb production and mate them to sires from mutton breeds. The other objective, either alone or along with the first one, was to breed the purebred $\mathrm{F}$ sheep under the prevailing subtropical conditions.

\section{Performance of purebred Finn}

\section{Adaptation to subtropical conditions}

F were reported by El-SHEIKH et al. (10) to be the least tolerant to heat stress and direct solar radiation under the Egyptian subtropical conditions compared to three local breeds, followed by the Suffolk, then Ile-de-France.

An interesting trial was carried out by EMOA to compare the performance of $\mathrm{F}$ ewes imported to Egypt with their half-sibs raised in Finland. Egypt group was significantly $(\mathrm{P}<.01)$ of higher rectal temperature and pulse rate than their half-sibs in Finland all the year round (1). Their respiration rate in the summer was almost double that of the Finland group. The response of $\mathrm{F}$ ewes to heat and exercise stress was also investigated in comparison with the local Egyptian sheep and their crosses under subtropical condition. Their physiological and performance responses were dramatically high (12). On the other hand, F-crosses proved to be more adapted to the prevailing subtropical condition. Their response to heat and exercise stress was closer to the local than to the F. Those of $1 / 4 \mathrm{~F}$ were almost similar to the local.

Purebred F sheep imported from Yugoslavia to Iraq were reported to be badly affected by the prevailing subtropical environment and hygenic conditions (H. KARAM, personal communication). The other flock imported later from Finland suffered from health problems (especially Pneumonia) and nonadaptability to the environmental conditions (F. El-DessouKY, personal communication).

The situation in Libya was worse, soon after arrival of the $F$ flock it faced many difficulties, mainly because of bad management. The big flock (500 heads) diminished drastically and the trial was completely terminated within two years (H. KARAM, personal communication).

\section{Reproductive performance}

Reproductive performance of $\mathrm{F}$ ewes was also affected under the subtropical conditions. Their fertility was not satisfactory in Cyprus (Hadjibanayiotou, personal communication) and they performed the poorest among different breed groups studied in the EMOA trial which involved two local breeds and different $F$ crosses (5). On the other hand, F sheep were able to maintain their high prolificacy, 
Table 1. Breeding plans for different NE trials with Finnsheep.

\begin{tabular}{|c|c|c|c|c|}
\hline Country and Organization & Started & $\begin{array}{l}\text { F sheep } \\
\text { imported }\end{array}$ & Breeding plan & References \\
\hline $\begin{array}{l}\text { - Ministry of Agricul- } \\
\text { ture, Egypt (EMOA) }\end{array}$ & 1970 & $\begin{array}{l}40 \mathrm{M}, 24 \mathrm{~F} \\
+8 \mathrm{M}^{*}\end{array}$ & $\begin{array}{l}\times \text { with } 2 \text { local breeds } \rightarrow 1 / 4 \mathrm{~F} \text {, } \\
\text { inter se mating for synthetic. }\end{array}$ & $\begin{array}{l}\text { ABOUL-NAGA (1987), } \\
\text { ABOUL-NAGA (1988) }\end{array}$ \\
\hline $\begin{array}{l}\text { - Agriculture Research } \\
\text { Org.. Israel (IARO) }\end{array}$ & 1970 & $23 \mathrm{M}$ & $\begin{array}{l}\times \text { with Merino and Awassi for } \\
\text { intensive lamb production. }\end{array}$ & $\begin{array}{l}\text { GoOt }(1975) \\
\text { EYAL et al }(1984)\end{array}$ \\
\hline $\begin{array}{l}\text { - National Academy of } \\
\text { Sc., Egypt (ENAS) }\end{array}$ & 1972 & $10 \mathrm{M}+10 \mathrm{M}^{*}$ & $\begin{array}{l}\times \text { with } 3 \text { local breeds } \rightarrow 1 / 2 \mathrm{~F} \\
\text { Suf. or Ile-de-France }\end{array}$ & ZAHED (1988) \\
\hline $\begin{array}{l}\text { - Ministry of Agric. \& } \\
\text { Nat. Reso., Cyprus } \\
\text { (CMOA) }\end{array}$ & 1972 & $6 \mathrm{M}, 22 \mathrm{~F}$ & $\begin{array}{l}\text { Pure } \mathrm{F} \text { and } \times \text { with } 2 \text { local breed } \\
\text { group } \rightarrow 1 / 2 \mathrm{~F} \times \text { Ile-de-France }\end{array}$ & AGROTI (1976) \\
\hline $\begin{array}{l}\text { - American Univ. Bei- } \\
\text { rut, Lebanon (AUB) }\end{array}$ & 1974 & $4 \mathrm{M}, 7 \mathrm{~F}$ & $\times$ Awassi and Texel & A.U.B. (1982) \\
\hline - FAO, Iraq (FIRQ) & 1973 & $5 \mathrm{M}, 25 \mathrm{~F}^{*}$ & Pure F & $\begin{array}{l}\text { H. KARAM } \\
\text { (P. Comm.) }\end{array}$ \\
\hline $\begin{array}{l}\text { - Ministry of Agricul- } \\
\text { ture, Iraq (IMOA) }\end{array}$ & 1979 & $15 \mathrm{M}, 175 \mathrm{~F}$ & $\begin{array}{l}\text { Pure } F \text { and } \times \text { with Hamadani } \\
\text { native sheep }\end{array}$ & $\begin{array}{l}\text { F. Dessoukı } \\
\text { (P. Comm.) }\end{array}$ \\
\hline $\begin{array}{l}\text { - Agriculture Research } \\
\text { Coun. Libya (LARC) }\end{array}$ & 1979 & $50 \mathrm{M}, 450 \mathrm{~F}$ & pure F. & $\begin{array}{l}\text { H. Karam } \\
\text { (P. Comm.) }\end{array}$ \\
\hline
\end{tabular}

* imported from second country other than Finland

number of lambs born/ewe lambed was 2.43 in EMOA trial and 2.3 in Cyprus. These figures are comparable well with the figures reported by MAIJALA (1984) under temperate conditions. Their lamb losses, however, were so high in both trials and ended by figures of 1.7 and 1.1 for lamb weaned/ewe lambed in the two trials.

One of the important findings in the EMOA trial is the mild seasonal fluctuation in the semen characteristics of the pure $\mathrm{F}$ rams, under the prevailing subtropical conditions. These mean that they can be used successively at any time of year, which is important for accelerated lambing systems. However, difficulties of the pure $\mathrm{F}$ rams to mate with the fat-tailed ewes were frequently reported in different trials. AI, and in some cases docking of the fat-tail, was used to come over this problem. Meanwhile, training the $\mathrm{F}$ rams on hand-mating with the fat-tailed ewes seems to be easy task in the EMOA trail.

When $\mathrm{F}$ ewes were mated each 8 months, their fertility was good in January mating season compared to the local breeds ( $70 \%$ ), but less in September $(54 \%)$ and only few ewes were mated in May (5). These figures are even less than the $60 \%$ reported by MAIJALA and
ÖSTERBERG (18) as an average out-of-season conception rate for $\mathrm{F}$ sheep in Finland and other temperature countries.

\section{Performance of Finn crosses}

\section{A) Reproductive Performance}

Prolificacy. Generally, F-crosses proved to be of higher prolificacy than the local breeds in different crossbreeding trials carried out in the NE. Improvement of prolificacy of the first crosses over the local breeds ranged from 18 to $75 \%$ (Table 2). A rough mean for reported superiority is $40 \%$, which is higher than $31 \%$ reported by Maijala (16) for the 1 st crosses with temperate breeds.

Results of other crosses rather than the first cross were reported in the EMOA and IARO trials. They showed that $1 / 4 \mathrm{~F}$ crosses were also of higher prolificacy than the locals but less than that of the 1st cross. Percentage of improvement over the corresponding local breeds ranged from 10 to $38 \%$ with an average of $24 \%$, (versus $11 \%$ for $1 / 4 \mathrm{~F}$ crosses with temperate breeds; (16). The Israeli trial involved some $3 / 4 \mathrm{~F}$ ewes, their prolificacy was $76 \%$ more than the local. 
Table 2. Reproductive performance of F-crosses in the NE under accelerated lambing systems.

\begin{tabular}{|c|c|c|c|c|c|}
\hline Genotype & $\begin{array}{l}\text { No. of } \\
\text { records }\end{array}$ & $\mathrm{EL} / \mathrm{EE}^{*}$ & $\mathrm{LB} / \mathrm{EL}$ & $\mathrm{L} / \mathrm{yr}$ & $\mathrm{LB} / \mathrm{EE} / \mathrm{yr}$ \\
\hline \multicolumn{6}{|c|}{ EMOA (mating each 8 months, Sept., May and Jan.). } \\
\hline Finn $(F)$ & 46 & .52 & 2.43 & .78 & 1.89 \\
\hline Rahmani (R) & 1512 & .72 & 1.31 & 1.08 & 1.38 \\
\hline FR & 743 & .77 & 1.68 & 1.16 & 1.91 \\
\hline $1 / 4 \mathrm{~F} 3 / 4 \mathrm{R}$ & 941 & .80 & 1.43 & 1.20 & 1.67 \\
\hline$(1 / 4 \mathrm{~F} 3 / 4 \mathrm{R})^{2}$ & 741 & .76 & 1.40 & 1.14 & 1.59 \\
\hline Ossimi (O) & 613 & .68 & 1.22 & 1.02 & 1.21 \\
\hline FO & 382 & .75 & 1.52 & 1.13 & 1.67 \\
\hline $1 / 4 \mathrm{~F} 3 / 40$ & 545 & .76 & 1.38 & 1.14 & 1.52 \\
\hline$(1 / 4 \mathrm{~F} 3 / 40)^{2}$ & 66 & .95 & 1.42 & 1.43 & 1.89 \\
\hline \multicolumn{6}{|c|}{$I A R O$ (in season and out of season matings with hormonal treatment) } \\
\hline Merino (M) & 382 & .79 & 2.00 & 1.17 & 2.35 \\
\hline FM & 434 & .76 & 1.84 & 1.24 & 2.34 \\
\hline FA (Awassi) & 365 & .84 & 1.99 & 1.45 & 2.90 \\
\hline FA & 266 & .84 & 1.65 & 1.36 & 2.31 \\
\hline $1 / 4 \mathrm{~F} 3 / 4 \mathrm{M}$ & 77 & .82 & 1.56 & 1.35 & 2.18 \\
\hline $3 / 4 \mathrm{~F} 1 / 4 \mathrm{~A}$ & 67 & .80 & 1.96 & 1.43 & 2.96 \\
\hline \multicolumn{6}{|l|}{ 1/2 Assaf- } \\
\hline $1 / 4 \mathrm{~F} 1 / 4 \mathrm{~A}$ & 102 & .80 & 1.51 & 1.39 & 1.66 \\
\hline \multicolumn{6}{|c|}{ ENAS (mating each 4 months) } \\
\hline Ossimi (O) & 2545 & .52 & 1.07 & 0.95 & .83 \\
\hline Rahmani (R) & 1951 & .41 & 1.10 & 1.04 & .68 \\
\hline Barki (B) & 1903 & .40 & 1.07 & 1.02 & .64 \\
\hline FR & 33 & .49 & 1.30 & 1.00 & .96 \\
\hline FB & 78 & .52 & 1.25 & 1.19 & .98 \\
\hline FO & 68 & .55 & 1.46 & 1.04 & 1.20 \\
\hline \multicolumn{6}{|c|}{ Cyprus (lambing twice a year) } \\
\hline Chios (C) & 53 & & 2.13 & 1.20 & \\
\hline FC & 8 & & 2.88 & 1.20 & \\
\hline
\end{tabular}

* EL: ewe lambed, EE: ewe exposed, LB: lambs born, L: lambing

Improvement of prolificacy in the $\mathrm{F}$ crosses with subtropical breeds is less than that expected assuming linear increase in prolificacy with the proportion of $\mathrm{F}$ blood, especially in the 1 st cross and higher $F$ crosses. The linear slope of improving prolificacy with increasing $\mathrm{F}$ genes found in the temperate crosses (17) is not clearly justified in the subtropical $F$ crosses. Failure of ova implantation or early embryonic losses in such high fecundity crosses under the subtropical condition may contribute to these discrepancies.

Inter-se mating of the lst $\mathrm{F}$ crosses (IARO) or 1/4 F (EMOA) does not seem to affect the prolificacy of the produced ewes (Table 2). Although it is still too early to judge the possibility of establishing synthetics of high fecundity and well adapted to subtropical conditions in the region, yet the results are encouraging.

Fertility. When $\mathrm{F}$ crosses were mated once yearly, fertility was generally less than that of the locals. Meanwhile, most of the NE trials applied some sort of accelerated lambing system for the $\mathrm{F}$ crosses to utilize the ability inherited from their subtropical parents to breed more than once/year (Table 2).

Number of lambings/year (L/Yr) averaged 1.18 for EMOA, 1.23 for IRAO, 1.08 for ENAS and 1.2 for the CMOA trials (Table 2). The more frequent lambing reported by IARO resulted from the use of hormonal treatment, whereas small number of $\mathrm{F}$ cross ewes were involved in the ENAS trial. An overall figure 
of $1.2 \mathrm{~L} / \mathrm{Yr}$ can be reported in this aspect, $v s$. 1.3 reported for different subtropical breeds (2).

Seasonal variation in reproductive performance and sexual activity. Although F crosses showed good ability to breed under accelerated lambing systems, yet seasonal variation in their reproductive performance was clearly noted in each of these trials. Seasonal differences in number of ewes lambed/ ewes exposed (EL/EE) or lambs born/ewes lambed (LB/EL) between autumn and winter (in season) and spring and summer (out of season) were substantial in the EMOA and IARO trials and significant in ENAS (Table 3). Seasonal differences in LB/EE were 39.5 and $39.2 \%$ in the first two trials, respectively. However, 1/4 F ewes in the EMOA trial showed less seasonal variation in their fertility than the lst cross, while it sustained seasonal variation in their prolificacy similar to other F crosses. Aboul-Naga et al. (5) speculated that high ovarian activity, including high ovulation rate, seems to be limited to the normal breeding season (fall), while during the prolongation of the breeding season, resulting from crossing with subtropical breeds, ovulation rates are maintained at lower levels.

The low seasonal variation in the fertility of $1 / 4 \mathrm{~F}$ cross ewes is in agreement with their consistent oestrous activity around the year even better than the local breeds (5). The 1/2 F ewes in the IARO trial showed oestrous activity similar to that of their local parent (7).

Both trials, however, reported ovarian activity during the anoestrous period of the $\mathrm{F}$ crosses as detected by the hormonal profile. This may explain the relatively high fertility results obtained out-of-season, by hormonal treatment in the IARO or by the ram introduction in the EMOA trials.

On farm trials. EMOA carried out on farm trials to test the performance of $1 / 4$ F-crosses under the breeders' and small farmers' conditions versus the local sheep at some villages in the Nile Delta area. The preliminary results were reported by ABoul-NaGA (3). With the rams run with the ewes all the year round, lambing intervals averaged 9.4 months for lst lambing and 8.5 months for adult ewes. Annual number of lambs born/ewe averaged 1.60 and 2.2 for the ewe groups respectively, and number of lambs weaned annually were 1.5 and 2.09 , respectively. These are rather satisfactory figures for lamb production under these conditions.

Some of IARO results were also reported from commercial flocks, especially those of crosses other than the lst cross. Results were as satisfactory as, or even better than, at the experimental farm (14).

Sexual maturity. One of the reported characteristics of the $\mathrm{F}$ sheep is their early maturity, ewe lambs usually mated at $7-8$ months of age (18). In IARO, $1 / 2 \mathrm{~F}$ ewe lambs tend to lamb earlier than the locals, especially for the Awassi crosses, where age at lst lambing were 404 days for the lst cross, 359 days for back-cross ewe lambs versus 457 days for Awassi. Furthermore, conception rate at first mating was substantially higher for Fcross ewes. Season of birth showed some effect on age at first lambing.

In EMOA, age at puberty was attained detectably earlier in the $\mathrm{F}$ crosses $(6.5-7.5$ months versus 8 months for the local). The $1 / 4 \mathrm{~F}$ ewes lambs attained puberty about 2 weeks earlier than the lst cross (ABOuL-NAGA, unbublished data).

Also F-cross ram lambs of AUB reached puberty early at $6-7$ months of age. AUB (8) stated that genes of early sexual maturity are transmitted through crossing with $\mathrm{F}$ sheep.

\section{B) Lamb and Carcass Performance:}

Lamb losses. Lamb losses during the lst 4 months of their life is an important criterion under the relatively harsh subtropical conditions especially for highly fecund sheep as the $\mathrm{F}$ crosses. Lamb losses were generally low for most trials, ranging from 4 to $12 \%$. In IARO it averaged $22 \%$ under experimental farm conditions, with similar loss rates for singles and twins and much higher for triplets or 
Table 3. Seasonal variation in reproductive performance of F-crosses in the NE.

\begin{tabular}{|c|c|c|c|c|}
\hline $\begin{array}{l}\text { Season of } \\
\text { mating }\end{array}$ & No. & $\mathrm{EL} / \mathrm{EE}$ & $\mathrm{LB} / \mathrm{EE}$ & LB/EL \\
\hline & \multicolumn{4}{|c|}{$E M O A$} \\
\hline September & 1743 & $.75 \pm .02$ & $1.23 \pm .04$ & $1.70 \pm .03$ \\
\hline January & 1552 & $.82 \pm .03$ & $1.10 \pm .04$ & $1.40 \pm .30$ \\
\hline May & 2225 & $.69 \pm .03$ & $.93 \pm .04$ & $1.42 \pm .04$ \\
\hline \multicolumn{5}{|l|}{ Seasonal } \\
\hline \multirow[t]{2}{*}{ differences } & & $* *$ & $* * *$ & $* * *$ \\
\hline & \multicolumn{4}{|c|}{$I A R O$} \\
\hline Nov.-Feb. & 690 & $.89 \pm .09$ & $1.74 \pm .30$ & $1.95 \pm .21$ \\
\hline May-Sept. & 362 & $.79 \pm .18$ & $1.25 \pm .37$ & $1.79 \pm .29$ \\
\hline Seasonal & & & & \\
\hline \multirow[t]{2}{*}{ differences } & & $* *$ & $* *$ & * \\
\hline & \multicolumn{4}{|c|}{$E N A S$} \\
\hline Jan.-Feb. & 1916 & $.42 \pm .03$ & - & $1.10 \pm .01$ \\
\hline May-June & 2239 & $.27 \pm .03$ & - & $1.11 \pm .01$ \\
\hline Sept.-Oct. & 2811 & $.53 \pm .03$ & - & $1.15 \pm .01$ \\
\hline \multicolumn{5}{|l|}{ Seasonal } \\
\hline differences & & ** & & $*$ \\
\hline
\end{tabular}

* significant at $5 \%,{ }^{* *}$ significant at $1 \%,{ }^{* * *}$ significant at $.1 \%$.

quadruplets. Lamb losses were higher in Merino than in Awassi crosses (14). Lamb losses were much less in the commercial flocks to average $11.5 \%$, the on-farm trials of EMOA showed also mild mortality rates of $8-12 \%$ up to weaning.

Growth and fattening performance. Generally, birth weight of F crosses was either slightly higher than or close to that of local lambs. Higher frequency of multiple births in the $\mathrm{F}$ crosses may contribute to these findings. Growth rates during suckling were generally higher than that of the locals $(19,14$, ABOULNAGA, unpublished data). Milk production from F-cross ewes was comparable to that of the native sheep but less than some other subtropical breeds known to be of good milk production, i.e. Awassi and Chios (IARO and CMOA).

Postweaning performance of $\mathrm{F}$ crosses varied greatly in different trials. It ranged from being less than the local breeds with daily gain of $164 \mathrm{~g}$ (ENAS) to high as $247-257$ $\mathrm{g} /$ day (9). Other trials fall in between these findings. From another point of view, different trials showed significantly earlier slaughter age of $\mathrm{F}$ crosses $(15,11)$.
Carcass composition. The most noticeable feature in the carcass composition of F crosses is the drastic reduction in the fat tail compared to the local sheep disproportionate to the $\mathrm{F}$ blood (Table 4), which represent lower marketability for these crosses in the region, especially for the lst cross or higher F crosses. On the other hand, F crosses showed significantly higher carcass fat percentage and less lean percentage than local breeds. Fattailed subtropical sheep breeds are known to have lean carcasses (aside from the fat tail), on the other hand, one of the main inferiority of the F carcasses is their less muscularity (18).

Using terminal sires on $\mathrm{F}$ carcasses for fat lamb production, i.e. Suffolk cross in EMOA and Suffolk or Assaf in IARO and Ilede-France in CMOA, does not seem to have favourable results in improving carcass composition of the produced lambs $(15,11,6)$.

\section{General conclusions}

1. Raising purebred $F$ sheep cannot be recommended under subtropical conditions, while their crosses, especially the lst and low- 
Table 4. Fattening and carcass performance of F-crosses in the NE.

\begin{tabular}{|c|c|c|c|c|c|c|c|c|c|}
\hline Breed & No. & $\begin{array}{l}\text { Daily } \\
\text { gain }\end{array}$ & $\begin{array}{c}\text { Slau- } \\
\text { ghter } \\
\text { wt. } \\
\text { (kg.) }\end{array}$ & $\begin{array}{c}\text { Slau- } \\
\text { ghter } \\
\text { age } \\
\text { (day) }\end{array}$ & $\begin{array}{c}\text { Car- } \\
\text { cass } \\
\text { wt. } \\
(\mathrm{kg})\end{array}$ & $\begin{array}{c}\text { Inter- } \\
\text { nal } \\
\text { fat } \\
(\mathrm{kg})^{*}\end{array}$ & $\begin{array}{l}\text { Tail } \\
\text { wt. } \\
\text { (kg) }\end{array}$ & $\begin{array}{c}\text { Fat } \\
\%\end{array}$ & $\begin{array}{c}\text { Lean } \\
\%\end{array}$ \\
\hline & & & & & EMOA & & & & \\
\hline Ossimi (O) & 18 & 181 & 27.9 & 154 & 12.3 & 0.64 & 1.2 & 12.0 & 66.6 \\
\hline Rahmani (R) & 15 & 179 & 38.1 & 154 & 14.3 & 0.44 & 1.2 & 11.0 & 68.1 \\
\hline $1 / 4 \mathrm{~F} 3 / 4 \mathrm{O}$ & 13 & 203 & 32.8 & 154 & 14.5 & 0.54 & 0.4 & 21.1 & 59.1 \\
\hline $1 / 4 \mathrm{~F} 3 / 4 \mathrm{R}$ & 24 & 196 & 32.7 & 154 & 14.5 & 0.50 & 0.6 & 20.0 & 59.0 \\
\hline $\mathrm{ScX} 1 / 4 \mathrm{~F} 3 / 4 \mathrm{O}$ & 21 & 196 & 32.5 & & 13.7 & 0.75 & 0.4 & 20.2 & 61.4 \\
\hline \multirow[t]{2}{*}{$\mathrm{ScX} 1 / 2 \mathrm{~F} 1 / 2 \mathrm{O}$} & 15 & 190 & 32.7 & & 14.0 & 0.65 & 0.2 & 23.7 & 58.8 \\
\hline & & & & & $I A R O$ & & & & \\
\hline Awassi (A) & 7 & 263 & 51.1 & 263 & 25.0 & 1.45 & 5.8 & $38.5^{* *}$ & 47.5 \\
\hline Merino (M) & 33 & 300 & 56.3 & 300 & 29.6 & 1.20 & - & 30.2 & 55.7 \\
\hline FM & 8 & 143 & 45.3 & 143 & 23.5 & 1.74 & 0.1 & 36.6 & 48.7 \\
\hline FA & 11 & 143 & 45.3 & 145 & 22.3 & 1.79 & 0.4 & 37.6 & 47.7 \\
\hline AsxFM & 9 & 139 & 46.2 & 139 & 23.3 & 1.87 & 0.2 & 33.7 & 50.7 \\
\hline AsxFA & 4 & 141 & 45.8 & 141 & 23.3 & 1.23 & 0.7 & 37.4 & 48.9 \\
\hline
\end{tabular}

* Kidney + gut fat.

** 1/2 Carcasses dissection included the tail.

Sc : Suffolk cross, As : Assaf.

er $\mathrm{F}$ crosses proved to be fairly well adapted to the subtropical conditions and can be utilized successfully to improve lamb production from local sheep.

2. Annual fecundity rate is a better indicator than prolificacy as it involves their ability to breed more than once/year, to be able to measure up to local ewes in that regard. High prolific sheep may not be the best sheep under subtropical conditions. Moderately prolific ewes, as the low $\mathrm{F}$ crosses, and able to produce more than once per year, would suit better to the prevailing subtropical conditions.

3. F crosses showed substantial improvement in the prolificacy over the local breeds. Their performance, however, is less than expected according to additive model, especially for the lst and higher $\mathrm{F}$ crosses.

4. Lamb performance of $\mathrm{F}$ crosses were generally satisfactory. They showed drastic decrease in their fat tail as compared to their local parents, however, their carcasses had higher fat content and were less lean than the local sheep.

\section{References}

1. Aboul-Ela, M.B., A.M. Aboul-Naga, T.H. Shala. BY, and K. Mauala, (1987). Physiological response to climatic change in Finnish Landrace ewes raised in Egypt and their half-sibs raised in Finland. Livest. Prod. Sci., 17: 179-185.

2. Aboul-Naga, A.M. (1985). Crossbreeding for fecundity in subtropical sheep. In: Genetics of Reproduction in Sheep. Ed. R. LAND and D. RoBINson, Butterworths, London.: 55-62.

3. Aвoul-NagA, A.M. (1988). Experiences of Finn-

sheep in the Near East region. Animal Production and Health FAO Publication (in press).

4. Aboul-Naga, A.M., M.B. Aboul-Ela and Ferial. Hassan (1985). Comparative study of oestrous activity in Finn ewes and Egyptian fat-tailed sheep under subtropical conditions. J. Agric. Sci. Camb., 105: 469-473.

5. Aboul-Naga, A.M., M.B. Aboul-Ela, H. Mansour and M. GABR (1988). Reproductive performance of crosses between Finn and nonseasonal Egyptian 
sheep breeds under accelerated lambing system. Small Ruminant Res. (Submitted).

6. Agroti, A.K. (1976). Performance of Finnish Landrace sheep under Cyprus conditions. Min. of Agric., and Nat. Res. Agric. Res. Inst. Reports Nicosia, Cyprus (in Greece).

7. Amir, D., H. Shindler, Marian Rosenberg, H. Gasitua and I. Dimerman (1984). The reproductive response of Finn-crosses to natural and artificial photoperiod, hormone treatment and introduction of rams. In: The promotion of prolific strains of sheep by nutritional and managerial means. Agric. Res. Org. Bet-Dagan, Intern. Publ., 201-212.

8. American University Beirut (AUB) (1982). Annual Report, Sheep Project, Grant Number 38-5554.

9. Cyprus Agriculture Research Institute (CARI 1980). Annual report. Min. Agric. Nat. Res., Nicosia, Cyprus.

10. El-Sheikh, S., I. Iвrahim, M. Salem, A. Моhamed and M. Youssef, (1982). Physiological adaptation of sheep to Sahara desert. Egypt. J. Anim. Prod. 21: 99-108.

11. Fahmy, Faten (1987). Studies on lamb production from some crossbreeding systems. M.Sc. Thesis, Zagazig Univ., Zagazig, Egypt.

12. Fawzi, Soheir (1986). Physiological studies on sheep: A comparative study on the heat tolerance of the Finnish Landrace, Rahmani sheep and their crosses. M.Sc. Thesis, Mansoura Univ., Mansoura, Egypt.

13. Gоот, H. (1975). Increased lamb production from
Finnsheep Mutton Merino crossbreeds in Israel. Wool Tech. Sheep Breed., 22: 18-22.

14. Goot, H., E. Eyal, W.C. Foote and D.H. MAtHEws (1984 a). The reproductive performance of Finn crosses in accelerated lambing programmes. In: The promotion of prolific strains of sheep by nutritional and managerial means. Agric. Res. Org. Bet-Dagan Intern. Publ.: 6-22.

15. Goot, H., E. Eyal, W.C. Foote and D.H. Mathews (1984 b). Body and carcass composition of Finn-cross lambs. In: The promotion of prolific strains of sheep by nutritional and managerial means. Agric. Res. Org. Bet Dagan, Intern. Publ., 51-65.

16. Maijala, K. (1980). Experiences of Finnsheep and its crosses as dams fat lambs. Symp. Intens. Sheep Prod., Helsinki, 1980: 2-9.

17. Maijala, K. (1984). Review of experiences about the use of Finnsheep in improving fertility. 2nd World Conf. on Sheep and Cattle Breed., Pretornia, 1984: 519-531.

18. Maijala, K. and Siv Österberg (1977). Productivity of pure Finnsheep in Finland and abroad. Livest. Prod. Sci., 4: 355-377.

19. Mavrogensis, A.P. (1977) Environmental and genetic factors affecting growth characteristics of purebreed and crossbreed sheep. Symp. Anim. Breed. Policy Med. and ME, Nicosia, 6-9 Nov. 1977.

20. ZAHET, S.M. (1988). The reproduction performance of some local breeds of sheep and their crosses with foreign breeds. M.Sc. Thesis, Al-Azhar Univ., Cairo. 